\title{
Andy Machals
}

\author{
“OF COURSE THERE IS NO SUCH THING AS A SOCIALIST \\ HANDSTAND, BUT ...": SOCIALISM, HUMANISM, AND \\ Virtuosity in East German VARIETy Theatre Practice \\ DURING THE 1950S AND 1960S
}

While researching the history of performance at Berlin's FriedrichstadtPalast I had come across this rejection of the idea of "a socialist handstand" many times, before I realized the extent to which the judgment had been qualified:

Of course there is no such thing as a socialist handstand, but there are many crucial elements in an acrobatic number, for instance the beauty of the human body, bravery, and concentration. An artistic presentation can be of humanistic character, but also of nihilistic character. But first and foremost, it must shape taste, and be pioneering. ${ }^{1}$

The author of this statement was Gottfried Herrmann, artistic and managing director of the variety and revue theatre Friedrichstadt-Palast in East Berlin between 1954 and 1961. In the 1920s, the theatre was known as the Großes Schauspielhaus, and it was where Max Reinhardt staged his large-scale productions of classical dramas and Erik Charell created the most lavish revue extravaganzas of Weimar Berlin. ${ }^{2}$ It was Charell's revue productions that gave the theatre its founding myth and secured its place in the public imagination. Today it still produces large-scale theatrical entertainments, albeit in a new theatre building built by the socialist government in the early 1980s and located on

Andy Machals is a Ph.D. candidate in theatre at the University of Bristol, where he is completing a dissertation on the performance practices of the Friedrichstadt-Palast. His study is funded by the University of Bristol Alumni Foundation. Machals is a practicing assistant director and creative producer.

I want to thank Kate Elswit, Catherine Hindson, Phillippa Spencer-Harrop, Peter Peasey, Kate Holmes, and Stephan Ehrig for their readings of this work and for enlightening conversations about the virtuosic labor of circus performance. 
Friedrichstraße, just across the street from the old theatre, the location for the productions this essay discusses.

I had never come across Herrmann's remark in its entirety because I had mainly been reading literature about the Palast's history written after German reunification in 1990. These writings were part of what Marion Kant described as a "deliberate writing and rewriting of German history since 1945," in which the cultural history of East Germany, that is, the German Democratic Republic (GDR), had been "shredded, assessed, reassessed, and reconstituted." 3 East German (theatre) history was examined mostly in terms of the failed state narrative that dance scholar Jens Richard Giersdorf attributes to East Germany's unique situation of having been "subsumed into the West German national structure" 4 after the fall of the wall. Accounts of the country's performance history, including those of the socialist handstand, were written as though they were merely part of this systemic failure, rather than being analyzed in relation to what they actually sought to achieve. The emphasis on a so-called failed project produced ideologically motivated and ahistorical readings of performance practices that failed to account fully for the potential of a range of socialist aesthetic experiments.

Five years after reunification, in his book on the history of the FriedrichstadtPalast, Wolfgang Schumann dedicated a chapter, entitled "The Socialist Handstand," to Gottfried Herrmann's tenure. In his ideologically motivated reading of Herrmann's invocation, he denied its aesthetic dimension. Schumann claimed that "there can't be a 'socialist' handstand, because there also isn't a 'capitalist' one." ${ }^{5}$ He used a political—not an aesthetic-opposition to demonstrate the absurdity of a capitalist, and thus also socialist, handstand. On the occasion of the twentieth anniversary of the New Friedrichstadt-Palast in 2004, Birgit Walter, theatre critic for the Berliner Zeitung, used Herrmann's phrase in abbreviated form-"Of course, there is no such thing as a socialist handstand"-to endorse her view of socialist entertainment theatre as apolitical, a view that she ascribed to the official party line. Entertainment theatre, in her reading, resisted the socialists' drive to control culture, because it simply lacked the kind of content that could be censored and controlled. She further explained that "[e]ntertainment in the GDR was basically known as entertaining arts. It belonged to socialist everyday life like canteen food and was taken seriously." 6 By linking the production of art to the making of canteen food, she understands the East German revue as merely mundane, rather than participating in the extradaily dimension of life normally associated with the aesthetic. Although the theatrical productions of the 1950s embodied hopes for the country's futures, Walter's historical perspective disguises these hopes by projecting the spirit of the country's end phase back onto its past. Neither Schumann nor Walter considered from an aesthetic point of view what Herrmann outlined after the "but." This misunderstanding fails to ask the more interesting question of what was it that really made socialist bodies move.

This article is about the aesthetic interpretation of the socialist handstand and its application to a wider set of physical practices at the Friedrichstadt-Palast. It argues that Herrmann's coinage of the socialist handstand was in fact a turning point in how bodies were understood in East German socialism and that this 


\section{Theatre Survey}

contributed to the development of a distinct Marxist physical practice. In considering the relationship among Marxism, theatre, and virtuosity by way of a humanist understanding of the capacities of the human body, this essay proposes to rethink the socialist handstand in terms of what I call "socialist virtuosity."

When Herrmann referred to humanism he alluded to a twofold argument that was prevalent at his time. Humanism in East Germany was employed as a way of marking a clear break with the Nazi past, and was at the same time part of an enduring German tendency to value the formation of "the whole human" through a combination of spiritual and bodily practices. ${ }^{7}$ In order to illustrate the artistic manifestations of the political and cultural conception of the moving body in socialism, the essay revisits what Giersdorf has described as the "vanished East German choreographic landscape" toire of the 1950s and 1960s, and the contemporaneous discourses in the circus and revue arts - to start a conversation about the world-making potential of socialist aesthetics in circus and variety performance. Herrmann's observation thus provides the starting point for a discussion of the late 1950s as a time when socialist theatre makers at the Friedrichstadt-Palast moved from a socialist theatre practice dominated by narrative to one grounded in the body and its physical practices. Consideration of the aesthetic dimensions of the socialist handstand also challenges the current periodization of GDR theatre, because it suggests that the revue prefigured a nationwide turn in the theatrical arts to thinking beyond narrative by about a decade. It also explains why the Palast took a detour via variety and circus performance in the 1950s and 1960s, embracing the revue practices of the grand production show that conveyed meaning through its socialist bodies, rather than its narrative.

In the 1950s, the GDR had just embarked on its socialist trajectory. ${ }^{9}$ Like all performing arts institutions of the time, the Palast scrutinized its institutional history in order to develop its practices in a socialist fashion. This was achieved through appropriation, which involved consideration of specific inherited objects and practices and how they appeared to the senses. The cultural appropriation was considered successful if ideologically inappropriate aspects had been silenced. ${ }^{10}$ In performance studies, and with reference to cultural memory, Richard Schechner discusses similar ideas in terms of restored behavior: "the processes of framing, editing, and rehearsing; the making and manipulating of strips of behavior."11 Reconstructions in a Marxist context are about rethinking the "as if" of what Schechner describes as subjunctive nonevents. Socialist futures always contained a good proportion of what had come before them, but these reconstructions happened in a specific context and to a certain end, rather than replicating a true original. In the 1956 revue Kinder wie die Zeit vergeht (Oh Boy, How Time Flies), for instance, the Palast revisited Berlin's most famous revue theatres of the 1920s, for example, the Scala and the Wintergarten. Although the show lacked a coherent character-based narrative, the revue reimagined in eight tableaux Berlin's variety and revue history in chronological order. In the revue's last scene, set in the year 1960, the Palast staged an image of how it imagined its own future as a socialist revue theatre. The revue's narrative structure implied the Marxist conception of history as a gradual development toward socialism and thus linked the Palast's 
own past to its socialist present and the future that East Germany was in the process of creating. In this way, some revues in the 1950s and 1960s devised new narrative structures that gave aesthetic expression to prevailing cultural dynamics. But since the majority of Palast revues were not structured as journeys through time but merely illustrated a specific locale (e.g., backstage areas or European cities), the bodies of the revue became the focus of attention. In this context, the reconstructionist dramaturgies mentioned above can be regarded as a prototype of how Marxist critical thinking became translated into revue-specific theatrical expressions. Herrmann's focus on the body must therefore not be misunderstood as a rejection of narrative, but rather as an attempt to find a different way of narrating socialist principles on the stage. The moving body just added another layer of conscious storytelling, and Herrmann's handstand marks the moment when socialist realist aesthetics passed into movement.

Herrmann used the handstand idiom to look at how the body participates in this process of cultural appropriation. The handstand is situated in a historical continuum of German movement culture and is indebted to German traditions of Gymnastik, physical exercise, and its nationalist manifestations in Turnen, which "focused on the education of a German, healthy, muscular, patriotic male battle force" 12 in the mid-nineteenth century. Gymnastik as a communal system fostered a body's abilities to form a physical national culture at a time when Germany was moving toward the formation of a nation-state. Herrmann alludes specifically to bodily control and to sets of exercises that aimed at "monitoring the production of the movement in the limbs ... at the greatest possible concentration of all capacities on the production process." ${ }^{13}$ This context shifts the focus of Herrmann's quote to his realization that "[a]n artistic presentation can be of humanistic character." The handstand, or any other physical practice, makes itself available to a project of cultural appropriation once it is understood as restorable behavior and subject to humanist fashioning. Here, Herrmann alludes to a third function of humanism that is unique to socialism. Besides the political dissociation from its Nazi past and its cultural ambition to form a whole human, the socialist aspect of humanism alludes to "the standardization of all our measures in matters of the whole human." "When Herrmann recalled Gymnastik's community-forging powers and humanist qualities, he implied that physical practice might also be used as a means to standardize bodies. In the course of the 1960s, his coinage was further explored by cultural scholars, whose concepts offer evidence of the cultural impact of Herrmann's idea of a socialist handstand as an embodiment of cultural, political, and socialist dimensions of humanism.

In 1960, Heinz Lauckner, for example, referred to the socialist handstand in order to argue that an acrobatic number could be a role model and thus provide a "vital socialist function." 15 Two years later, Horst Blumenfeld reframed the idea of the socialist handstand as a "modernization index" to measure the socialist viability of an act. ${ }^{16}$ The humanist values at the heart of the idea of socialism came increasingly to define the aesthetic qualities of the physical practice in revues, because it was these values that shaped its affect. In his work on political bodies in dance, Mark Franko states that "affect occurs when dance has transmitted the essence of a feeling." 17 This definition of affect slightly changes in its application 


\section{Theatre Survey}

to Marxist physical practice, because this essence is to be found in the dramaturgical thinking of movement practice. Forms of scripted affect made visible a Marxist understanding of movement as labor. The resulting socialist forms of circus practice reimagined the moving body in accordance with the socialist conceptions of humanism, as I explore in the final section of this article. But in order to understand fully the premises of these scripted affects, I introduce humanist narratives of early GDR revue theatre, so as to describe how these narratives were translated into experiences of virtuosity and affect.

\section{FROM HUMANIST NARRATIVE TO SOCIALIST BODIES}

Humanism appeared throughout the GDR's cultural history, albeit in differing manifestations and with decreasing leverage toward the latter half of the country's existence. When the GDR began to function as a state in 1949, the goal of "true humanitarianism" was noted in the section on education in the first constitution. ${ }^{18}$ At the same time, Palast shows came increasingly to incorporate classical ballets, and their narratives were revised to express socialist ideas. While humanism became the country's cultural legitimization, a "national policy category [staatspolitische Kategorie]," and eventually a strand of Marxist-Leninist thought structures ${ }^{19}$ the moving body itself became the subject of critical debate in discourses about training and practice. These approaches to the moving socialist body in both discourse and stage practice were underpinned by a shared reliance on the concept of humanism that resulted in different theatrical manifestations. The translation of the concept into theatre emanated from the notion of humanism as a function of the GDR's Menschengemeinschaft, community of human beings. ${ }^{20}$ Therefore, the development outlined in this section describes how the Palast and other players in its industrial field learned how to understand humanism as a principle of both production and reception. However, this could only be achieved if humanism was understood in terms of labor. Only then would humanism have a clear socialist dimension and the moving body itself be able to produce and transmit an appropriate feeling and achieve its scripted affects. The growing understanding of the body's capacity to produce meaning in its own right challenged the conventional narrativity of the Palast revues, whose inner coherence had conventionally been achieved through a common theme or a meaningful idea. In the end, socialist humanism, when translated into movement, destabilized the conventional dramaturgies of the revue by stabilizing the body through standardized meaning-making processes.

When circus performer Marion Spadoni reopened the Friedrichstadt-Palast in 1945 (then under the name of Palast-Varieté), her shows were formally presented as variety programs. ${ }^{21}$ Circus acts complemented specialty acts and were framed by dance numbers and orchestral renditions. The clear distinction between bodily practices is also reflected in the German language, which does not provide a word that encompasses aestheticized performing bodies in general. Instead it distinguishes between Tänzer, "dancers," and Artisten, "circus performers." The GDR dictionary for entertainment arts, Unterhaltungskunst A-Z, has Artistik on record as an art form whose presentations' "contents are autonomous within an 
entertainment program." 22 Artist and Artistik exist in the same relationship as the dancer (as the executor) relates to the dance (an umbrella term for several bodily practices). This conceptual distinction has caused Artistik and Tanz to be regarded as independent forms of bodily labor, with Artistik being the essential element of the Palast show between the 1950s and the early 1970s, and dance leading a second-order existence primarily as insert or act finale during that period.

Spadoni's successor, Nicola Lupo (Palast director between 1947 and 1954), extended the proportion of dance and incorporated classical ballets into his variety shows, which also gave the shows their name, like Coppélia in the February 1953 program. After Spadoni's nonnarrative variety programs, Lupo's return to narrative conveyed through ballet as an underlying narrative for an otherwise loose arrangement of variety performances suggests how a ballet's improved narrative was to furnish the revue's humanist character.

With its return to narrative forms of the ballet, the Palast reflected a national search for a standard vocabulary of socialist dance. Discussions about this search peaked during the first conference on "Realism in Dance" in 1953. It was organized by the Staatliche Kommission für Kunstangelegenheiten (the State Commission for Artistic Affairs) in order to determine the dancing body's position in a framework of socialist meaning making in the theatre. Leading up to the conference, delegate Martin Sporck, ${ }^{23}$ in his article in the Weltbühne, asked: "Is dance actually a genre of art in its own right? Does it have specific features that distinguish it from all the other arts?" 24 He ended his polemic by endorsing new narratives, instead of new forms of dance: "What we need are new ballets, socialist in content and national in form." 25 His provocation tried to standardize a discourse on the creation of movement as being dependent on its narrative framing only. Movement in new works was thus developed in terms of a literary text. This stance illustrates that socialist realism was thought of as the depiction of a narrated process. According to Jens Richard Giersdorf, "socialist realism not only depicted and critiqued social structures but also supplied the way out of the contemporary societal system and into a brighter future via socialism." ${ }^{26}$ Art, including dance, was generally understood in literary terms, and as working through and upon the understanding rather than the body. A nonliterary art such as dance, therefore, could not be understood to have an existence independent from the narratives it was supposed to present.

Lupo's ballet revues illustrate how these early attempts to translate socialistrealist doctrine into bodily practice were in fact about its narrative framing. Whereas dance's ideological potential lay in its capacity to shape audience response by narrative means, circus performance, lacking this referential quality, did not seem to offer the same potential for the communication of socialist values. Therefore, the necessary socialist-realist critique was constructed through reworkings of the ballets' narratives so that they delivered humanist statements. For instance, Lupo's April 1951 program dubbed Polowetzer Tänze (Polovtsian Dances) featured Alexander Borodin's famous ballet insert from his posthumously completed 1890 opera Prince Igor. Whereas the original opera scene is set in the Polovtsian camp where Prince Igor is held captive and the Polovtsian maidens dance to victor Khan Konchak's glory, the Palast rendition told the story as an 


\section{Theatre Survey}

attempted escape of the nameless maidens, who had apparently been captured by the Tartars. After Khan's command to bring the "exotic, blonde beauty" 27 into his tent, the captured slave women are upset and wake the whole camp. "The ensuing dances mirror the unspoiled temper of this tribe." ${ }^{, 28}$ In the early postwar years, the Palast staged dance in a context that concerned the fate of slaves, not princes. Although the archive does not provide sufficient evidence as to how much the actual stage choreography in fact deviated from that which supported the original story, it does show that the ballet had been reframed by alternative narratives.

When Herrmann succeeded Lupo as director, his work linked numerous dances through the narrative of a book revue. This new integrated form of revue combined dance, music, circus acts, and spoken narrative, all motivated by a coherent story. ${ }^{29}$ The 1954 hit show Einmal am Rhein (Once upon a Rhine) featured folk dances that emanated organically from a constructed narrative: once the river steamer sets sail and the captain, the mate (a comedian), "sailors of the Friedrichstadt-Palast" 30 (the male dancers), jugglers, magicians, trapeze artists, some real sea lions, and "the dancing fishes" 31 (the female dancers) have entered the boat, a series of stories illustrated the joys of a Rhine cruise. Dances of Einmal am Rhein were imagined in a context of folk aesthetics that created a sense of ancestry and shared local history, based in a perceived humanist German tradition. At that time in the GDR, folk was used to "construct a national identity distinct from that of West Germany, which laid claim to all of German history and culture." 32 The folk movement extended into areas of literature, music, and dance; in dance it entailed not only its aestheticized stage forms, but also forms of community dances. Herrmann used folk's "potential to manufacture localized and national community identifications" 33 by assuming that folk aesthetics actually displayed an East German identity. Folkloristic aestheticizations of any given content therefore engendered a distinct socialist reading of the world. In the wine cellar tableau, for example, the Dance of the Spirits of Wine, performed by the women of the corps de ballet, was framed by the cellarer's song recitals (Otto Hiller) and a clown act by tipsy Speedy Larking. The revue showed all that could happen if the Friedrichstadt-Palast ensemble and orchestra were put on a riverboat together with a group of specialty performers. This revue becomes culturally relevant because it extended an East German project of humanist world-making potential in the form of dance and acrobatics to the West German river Rhine. Conceptualizing the Rhine and its surrounding cultural landscape of the Rhineland in the terms of socialist aesthetics appropriates an important German memory landscape. In his study of the formation of a German national memory, Rudy Koshar describes the Rhineland as representing an important and founding aspect of the German "national spirit by depicting medieval castle ruins and natural settings as parts of a German cultural landscape independent of states or contemporary political boundaries." 34 Additionally, the West German capital of Bonn and numerous Prussian monuments commemorating the German unification of 1871 are also located in the Rhineland. Einmal am Rhein shows how cultural producers of East Germany used the GDR's conception of folk projected onto a West German memory landscape in order to accommodate the official party line in their socialist narratives. These had been geared toward a 
model of German reunification that preserved the social achievements of the GDR. ${ }^{35}$ This revue taps into the same mind-set of socialist cultural markers extending into an imagined West Germany.

Outside the theatre, the ways in which the socialist moving body was imagined progressively changed. Parallel to Herrmann's book revues and the official party strategy to aim for German unification, party tactics involved confrontation with capitalist influences and the development of truly socialist structures of thought. This included the development of an explicitly socialist regime of physical training. The establishment of the State School of Circus Arts in Berlin shaped the performer's body prior to entering the industry, and the founding of Artistik magazine created a forum for the exploration of how existing practices in the industry might be developed along socialist lines. These developments eventually conditioned Herrmann's proposal to shift attention away from narrative and toward an emphasis on the performer's body and labor only three years after Einmal am Rhein.

Artistik magazine, founded in 1955, was a magazine for professionals published by the arts union to discuss how to develop the arts of revue and circus not only in terms of dramaturgy and framing, but also of notions of practice, virtuosity, and working conditions. ${ }^{36}$ In terms of the Marxist acquisition of performance practices, Artistik ensured a particular reading of sedimented practices of the past. Whereas the narratives of the revues in East Germany could easily be controlled by dramaturgs, bodily practices such as dance and circus performances were much more equivocal in the way they produced meaning. Consequently, Artistik was a way to police bodily practice through writing about it. It helped shape the GDR's superstructure and offered a public platform through which discussions about the aesthetic challenges and structural changes could take place. An examination of the magazine's back issues suggests that responses to party dictates were highly sophisticated and even polyvocal, with theatre directors, dramaturgs, creative directors, choreographers, costume designers, program directors, critics, and political officials contributing to the discussions, channeling their understanding of socialist realism. This is why Artistik is a good barometer for thought, as its discussions not only channel how doctrine affected programming of the repertoire, but also hint at how the importance of the body increased over time. This was primarily evidenced by debates over future forms of socialist theatre and training establishments.

One year after the founding of Artistik, the Staatliche Artistenschule, the State School of Circus Arts, was founded in East Berlin. It focused on the "systematic nurturing of young talent [in order] to secure the future of the circus arts." ${ }^{, 3}$ The former custom that circus performers were educated within their own families was replaced by a state-sponsored education, removing training from its lowermiddle-class origins. Inge Regener, member of the Ministry of Culture, described the tradition of the performer family as having developed in "societally unfavorable conditions" 38 of presocialist times. Although circus semiotician Paul Bouissac does not refer to socialist circus education, he does describe this lower-class standing of circus performers: "The circus originally was a strategy of ephemeral acceptance and precarious survival devised by ethnic minorities 
that were not allowed to settle for business in villages or towns." ${ }^{\text {,3 }}$ Ephemeral communities produced spectacles that drew on the performers' otherness. Such problematic labor conditions were no longer compatible with the GDR's humanist aspirations to a postclass society. The traditional ephemeral communities were deemed unable to produce, in the eyes of the socialists, relevant socialist art. The traditional education of artists within their own communities was thus replaced by state-sponsored education, removing training from the class context it had occupied under conditions of capitalist production. The school not only promoted performance skills, but also focused on making their students "helpers in the construction of our new society." 40 Initially, each cohort comprised fifteen to twenty students who had to master four years of training. The first year focused on skills training (gymnastics, dance, acrobatics, juggling, high wire), while in the second and third years, the students advanced in one of the skills. The final year focused on compiling sets of skills into an acrobatic number. All students received training in languages (Russian, English, French), history, musicology, rhythmics, and Marxist aesthetics. The establishment of the national training institution suggests that the body was recognized as having substantial socialist potential. Artistik contributor Tilo Vogel comments: "We are particularly keen on fostering aesthetic aspects [to] establish an artistic style applicable to us."41 Still, this seemed to be tied to a narrative framing, as circus arts were "to be filled with socialist content." 42

While these structures of socialist cultural production were established, humanist ideas were repeatedly proclaimed as essential for variety performance. In 1955, Harry-Heinz Neumann pronounced that

[b]uilding a new German culture, that is imbued with a humanist spirit and true democracy, in all areas of the fine and performing arts of the German Democratic Republic also requires the acrobats to let go of the notion of "Whatever pleases (the audience) is allowed" [Erlaubt ist—was gefällt $].{ }^{43}$

This gives revue practice a key political role in the engineering of the new society. Through humanism, artists were meant to construct a countermemory by altering an existing, sedimented set of movements. In other words, artists were meant to acquire and embody the past by appropriating these practices in humanist terms. This reconceptualization is the essence of Marxist cultural appropriation. Performance scholar Joseph Roach describes similar cultural practices in terms of kinesthetic imagination. If we were to think in similar terms about the project of cultural appropriation in the GDR, Roach's definition helps to frame Neumann's polemic as a "transmission (and transformation) of memory through movement." ${ }^{44}$ Such cultural processes always involve a reconstruction and reinterpretation of practice that corresponds to what Roach calls a "specialized social organization." 45 Humanism was used to mobilize theatrical practices and force dancers and performers to rethink their stage behavior. Neumann went on to proclaim that the GDR was not in need of "memory artists [Gedächtniskünstler] ... who are not willing to enhance their performance [Leistung, as in achievement] through the development of new tricks and new approaches."46 Marxist cultural appropriation sought to shape taste by rethinking the body's practice, but it had 
not yet been able to provide a common language, either spoken or as movement, that would allow practitioners to identify and reshape specific behaviors that had come to be understood as capitalist vestiges.

Such a countermemory about practice was also created by Gottfried Herrmann's 1959 revue Ein Ball rollt um die Welt (A Ball Rolls around the Globe), which turned the practice of juggling into a genre fable and demonstrated a strong desire to shape the bodily stage practices of circus, although with no coherent approach as to how this was meant to be done. In this show, Herrmann illustrated the ideological difference that the socialist reading of humanism can make when the labor of Soviet and Western variety practices are compared. Inspired by the life of juggler Enrico Nardini, the Palast fable imagines the life of Italian Russian-trained juggler Enrico Rastelli and follows the performer across Europe, starting in 1908 in an unnamed Russian town, and on to Chicago, where he is betrayed by greedy managers. The revue ends in 1950 at the State Circus of Leningrad. The revue sought to show that a practice is affected by social conditions. The program booklet explained this process by describing the practice by way of its object, the juggling ball, whose social contexts were eventually intended to be seen as influencing Rastelli's practice:

[The juggling ball] rolls, driven by the fanaticism of a person possessed by his endeavor, it rolls, driven and harassed by the managers' greed for money, and it eventually rolls in beautiful harmony toward a happy future. Let's attend to the ball and the one who juggles it. ${ }^{47}$

The revue was accompanied by an exhibition on juggling in the theatre's foyer. By exhibiting the material culture of an artist's labor, the Palast demonstrated its genuine interest in the techniques of the juggler, on and off the stage. It also shows that the Palast increasingly tried to move beyond narrative in its attempts to develop a theory of the socialist laboring body. On the stage, however, the revue's objects - that is, "the identifiable elements that contributed to the meaning of the acts" ${ }^{\prime 4}$ - were still not the performance practices per se. Instead, the revue staged recognizable elements of contextual narration (mostly through geographical markers) and the juggling ball itself. Theatre critic Werner Hoerisch appreciated how the display of localities related to ideological implications: Rastelli was betrayed in capitalist Chicago, but had his greatest success under humanist conditions in Leningrad. The actor playing Rastelli, Ernst Kuhn-Montego, portrayed the practice of the original Nardini "most convincingly" 49 in that he "marvelously mastered the fascinating language of the cunning play with clubs, hoops, and balls." ${ }^{50}$ Hoerisch does not indicate whether or not Rastelli's movement actually responded to the changing geographical contexts. According to the program booklet, this "how" was to be deduced from the context of the tableaux: "Although some juggling acts may seem similar at first sight, if you look again, dear spectator, it's never really the same. It's not about what is juggled with, but the how is crucial. ${ }^{, 51}$ This written intervention into the ways in which the revue was intended to be watched demonstrates how the Palast had a sincere interest in conveying the juggler's labor. Although Hoerisch still located 


\section{Theatre Survey}

this "how" in the revue's dramaturgical translation of Marxist humanism, his account illustrated that practice was understood as a form of labor that can be illustrated by its context, but not yet necessarily by the portrayal of its kinesthetic attributes.

In the next section I turn toward what I am calling "socialist virtuosity," which involves the conceptual shift of stepping beyond narrative to a consideration of the artist's labor as such.

\section{THE LABOR OF SOCIALIST VIRTUOSITY}

In the late 1950s, it was not only at the Friedrichstadt-Palast that people talked about bodies. The whole field of the circus and variety arts tried to find ways that would acknowledge the significance of moving bodies beyond the narratives of the shows into which they were incorporated. The development of socialist virtuosity was in fact the answer to a conceptual paradox engendered through the combination of understanding the performer's body in Marxist terms of labor and the interpretation of that labor in terms of socialist realism. But before the conceptualization of socialist virtuosity can be fully grasped, the history of this stage practice as a means to step beyond narrative must be noted. It starts by revisiting Herrmann's socialist handstand and what it actually offered to practitioners in the field.

In December 1959, Artistik published a comment piece by Herrmann, entitled Noch keine einheitliche Linie in der heiteren Kunst ("Still no uniform line in the art of amusement"), based on a speech he gave during the Fourth Central Delegate Conference of the Arts Union of the GDR. ${ }^{52}$ This is where Herrmann's socialist handstand appeared for the first time. He actually used the term to take issue with a regulatory framework, introduced in 1958, that aimed at validating all performing artists. In the country's search for a socialist aesthetic for die heitere Muse ("the arts of amusement"), that is, variety and revue performance, the state employed the administrative means that it had available. But to Herrmann, these were of little use in his attempts actually to shape a bodily aesthetic toward the socialist project. Although the Ministry of Culture had worked meticulously to screen performers' acts for quality-it had received 1,325 applications, of which 800 applicants received their vocational certificate ${ }^{53}$ Herrmann referred to this process as merely "insightful" 54 and saw it as a political tool only, as it did not help him in describing what "socialist" actually means in terms of attitudes and performance practice. Heinrich Martens, Palast dramaturg at the time, named the aspects under which the practices submitted by performers for licensing were reviewed "[i]dea, originality, difficulty level, execution, equipment, score and background music, speaking technique, voice leading." 55 But in Herrmann's view, the framework did not define how those markers were supposed to foster uniquely socialist aesthetics. Like the founding of Artistik magazine, the validation process sought to achieve some measure of bodily conformity to new socialist norms. But at the same time it was also more systematic in that no performing artist was able to evade the scrutiny of their skills and aestheticized labor. Politically, the validation process generated a rhetoric of exclusivity that 
positioned socialist ideals above anything else. Herrmann's colleague Hans Obermann, director of the Leipzig cabaret Pfeffermühle, proudly stated that their profession had been "pruned of amateurs and of cultural-politically inferior performances. ${ }^{, 56}$ Technique was still subjugated to dramaturgical framings and political intentions.

By offering the idea of the socialist handstand, Herrmann started to rethink those narrative framings and shifted the focus to the performing body itself. In the typical rhetoric of the time, he first denied, then further developed that which he had just rebuffed: "Of course there is no such thing as a socialist handstand." But by continuing that the "socialist" descriptor should actually embody "humanist character," Herrmann lends his thinking cultural relevance. Being a theatre director himself, Herrmann expressed the need for a vocabulary that enabled him to move bodies in ways that would form a reproducible aesthetic rationale for socialist performance practice. His main concern was about how to continue and encourage the validated artists to engage in socialist aesthetic practice, now that they had secured their licence to perform.

In Herrmann's handstand, markers of humanism thus become vehicles for a socialist aesthetic. Dance scholar Judith Hamera notes that a "metaphoric technology" ${ }^{, 57}$ organizes the relationship between a moving body and its beholder. When words and concepts of thought begin to coordinate movement practices, it is through this conversational vocabulary that movement gains legibility beyond the moment of its ephemeral performance. She calls this link between doing and conversing "technique" and uses it to describe the community-forging practices in the rehearsal room that eventually produce aesthetics through conversation. I use her approach in reverse, starting at a conversation about the ephemeral moment to make assumptions about how practices were imagined and eventually formed. Technique in its conversational function "shapes its object-body, making it available for conversation, and actual reading." ${ }^{58}$ Although the socialist handstand had been a descriptive term, Herrmann tried to identify those qualities of the performing body that could potentially make it socialist by using humanist terminology to describe it: "but there are many crucial elements in an acrobatic number, for instance the beauty of the human body, bravery, and concentration." He employed these descriptions to create what Hamera refers to as a "synecdoche [of technique]": ${ }^{59}$ a network of tropes that form a complex rhetoric figure, and eventually enable specific aesthetics. Through this vocabulary, Herrmann allows for the artist's movement to enter a discourse of socialist performance. In this context, metaphors and stories are the devices that animate the body and shape the "social lives of aesthetics. ${ }^{, 60}$ By shifting his focus to the body, Herrmann opened the field to a discussion of socialist practice beyond the existing narrative and political concepts, like "bourgeois" or "cosmopolitan" as categories of Palast dramaturgy. ${ }^{61}$

The socialist handstand, when read as a metaphor for technique- that is, for codes that will eventually "gover[n] and standardiz[e] dance practice" aesthetic dimension that is also rooted in a Marxist understanding of stage labor. In Marxist thought, when a body moves onstage, whether in dance, in acrobatics, or specialty acts, a performer's movement is physical labor and her body is her means of production. The product of a handstand performer's labor is the objectification 
of that labor. In other words, the handstand, as both labor and object, is consumed by onlookers while the performer labors it forth. In his idea of the handstand Herrmann stresses this state of affairs in his demand that the "crucial elements" need to "shape taste," through the exhibition of the "beauty of the human body, bravery, and concentration." Although these are primarily attributes of the performer, they are also meant to influence the beholder in her act of watching and to forge a community of onlookers. A socialist performance, in Herrmann's eyes, is supposed to spark a conversation between the laboring and watching bodies. This relationship between the body laboring forth movements and the act of consuming this display is a conversation that Hamera describes as virtuosity: "labors that exceed any 'self' expression of the artist." ${ }^{63}$ Reading the socialist handstand in this light suggests that its "crucial elements" were to organize the body so as to provoke "interpersonal, vicarious, intimate conversations between artist and spectator/critic." 64

Finally, according to Herrmann, socialism had aesthetic implications that first and foremost had to be vorwärtsweisend, "pioneering." This notion gestured toward the future, evoking embodied manifestations of socialist realism's dramatic function of Perspektivebewusstsein, "prospective consciousness," 65 "an account of the forward-thrusting, dynamic historical movement from a problematic present to a better future." ${ }^{, 66}$ On the one hand, this makes Herrmann's handstand an invocation to explore what might be possible under the umbrella of humanist performance practice. On the other hand, it had very clear parameters set by notions of both humanism and socialist realism.

Conceptually, however, these notions of futurity were actually at stake because of a paradox arising from the pressures that socialist-realist production exerted on Marx's concept of alienated labor. In performance, a performer's means of production, her body, labored forth the product (e.g., a handstand), which is her body's aestheticized movement and which is consumed by the onlooker. The paradox arose when the principles of socialist realism entered this conversation: her body, although it is her means of production, engendered the objectification of her labor, which is supposed to illustrate the future by means of humanism. This paradox required the audience to see her body and what she labors forth as two different things at the same time. Her means of production and the objectification of her labor were visually the same; but socialist virtuosity was meant to illustrate this distinction by way of specific narrative references.

Priya Srinivasan argues that "[i]n the aesthetic realm, audiences are trained not to see the labor of dance, but they are still consumers of that effort." ${ }^{, 67}$ In Marxist physical practice, however, the labor was mean to be seen, and the effort, which was produced under humanist conditions, was meant to be displayed as a positive thing. Audiences were compelled to see humanism - that is, a representation of both the country's future and its means of getting there-as an inspiring task. In their Artistik special issue Die Zirkuskunst in der Deutschen Demokratischen Republik ("The Circus Arts in the German Democratic Republic") of 1964, Heinz Lauckner and Mario Turra emphasize conversations in which humanist fiction was used to forge commitment to the socialist idea: 
"We are not thinking about sensations based on thrills in which the human takes a backseat. But we need acts that are implemented in a way that audiences talk about them and are eventually drawn to attend." ${ }^{68}$ By delineating socialist performance from spectacles based on thrills, they seem to refuse conventional ideas of virtuosity, like "heroism, mastery, talent," ${ }^{19}$ in order to replace them with socialist scripts:

To arouse pride in the human performance capabilities through high-quality circus performance and animal training. To inspire people to achieve high performances themselves through displaying top-class circus presentations. To allow audiences to make an aesthetic evaluation of that which is beautiful through the spectacle of fine bodies in accomplished movements. ... To arouse pride in the distinguished accomplishments of the circus of the GDR through splendidly executed circus performances. ${ }^{70}$

Lauckner developed these scripted affects to promote positive efforts, like "bravery, power, athleticism, affirmation of life," but only if "outstanding performances are mastered with ease, charm, and elegance." 71 Such performances were to tease out a "liberating laughter," understood as labor, are presented in a kind of aesthetic alliance with the thrills and the sensations of conventional performance. In Lauckner's analysis, socialist virtuosity emerges as a split between excellent body control and its humanist positive framing. "[P]erformers and animal trainers can perform through their art and exemplary appearance, a vital socialist function," he continued, alluding to humanism's capacity to create that perceptible gap between the body as the artist's means of production and the objectification of her labor. These affects were eventually intended to create a longing for the socialist sense of life. However, this longing could only be realized if the "fine bodies in accomplished movements" "73 brought them to life.

In order for the audience to see the body's labor as different from its objectification, the body's techniques also had to receive a socialist makeover. Making a technique socialist thus involved the application of practices of cultural appropriation. Considering the volume of words devoted by Artistik contributors to delineate primarily bourgeois forms of sensationalist performance from an as yet defined socialist kind, any technique ought to avoid the reproduction of what Vicky Lebeau called "pre-existing patterns of fascination," "74 associated with conventional bourgeois forms of virtuosity. These capitalist vestiges of circus performance aesthetics were to be transformed into something else because, in a socialist society, they had lost their meaning.

In order to find what Herrmann called the "uniform line in the art of amusement" - that is, a form that standardized movement practice and appropriated bodily knowledge from the past-Waltraud Kropp and Heinz Schröter offer aesthetic strategies for East German variety practice in another Artistik special issue, Die Bedeutung der Tanzkunst für die artistische Arbeit ("The Importance of Terpsichorean Art for Variety Labor"). They propose to reimagine variety practice vocabularies in terms of classical dance. Kropp and Schröter begin from their 
perception that training in circus performance lacks engagement of an all-around body. This perception, like the idea of the noncompetitive handstand itself, clearly draws on existing notions of a German physical culture. According to Kropp and Schröter, dance benefits from an "all-around development of musculature, jumping and lifting powers, steadfastness, back tension, expressive arm movements, technique of turns, harmonic movements and postures." 75 The routines of ballet's classical exercise would then provide a coherent "system of scenic movement" for circus performers. ${ }^{76}$

This idea gains even greater significance if the position of the classical exercise of Russian style is considered in relation to other schools of ballet. Working within the same ideological framework, Russian dance pedagogue Nikolai I. Tarassow argues that the Russian school, in a highly academic fashion, combined the French tradition, which "is characterized by rich compositional techniques, an elegant manner, and soft movements," 77 with the Italian tradition, which stands for a "virtuosic technique and a strict style." ${ }^{, 78}$ The perceived stylistic totality of the Russian-style classical exercise further fertilized Kropp and Schröter's ambition to combine it with circus techniques to shape aestheticized labor onstage, because it would support the "fostering of creative expressiveness."79 But such a consistent Körperschule ("school of the body") was lacking in all disciplines of circus practice training. In their analysis, circus performance of past epochs had been regarded an "isolatedly drilled, individualistic sensational presentation that quite often compromised the performers' well-being and life." 80 Dance techniques were meant to change an act's compositional structure by means of choreography, blurring the boundaries between their actual objects and their framing.

\section{THE UNIFORM LINE OF SOCIALIST VIRTUOSITY}

The historiographical challenge is in locating in the archive whether the two things, the body and its labor's product, where in fact seen as separate; and further, what that perception did to the socialist bodies of the Friedrichstadt-Palast's practice in the long term. In order to do so, it might be worthwhile to think first about the practicability of a concept like socialist virtuosity and how it had been proposed by the writers discussed above. Despite the fact that circus practices are multiform and each practice in fact requires unique training methods, socialist virtuosity aspired to create a method that subsumed circus practices under the framing techniques of ballet. Its classical exercise would indeed lead to a holistically trained body, but it would also train musculature in ways that could obstruct the development of particular techniques for specific circus acts. The production of aestheticized labor was brought into accordance with its consumption and required, obviously against the grain of any particular practice, a homogeneity in which the productive labor of movement was covered by a scripted affect based on elegance and pride, evoking readings of effortless labor. This contradiction causes socialist virtuosity, as a fully fledged concept of some considerable world-making potential, to be traceable primarily in discourse rather than in actual stage practice. But a growing confidence in the socialist body can be attributed to 
the development of socialist virtuosity, thus allowing for the bodies of the revue to make sense over and above narrative content and the folk aesthetics of the 1950s. Whereas, in the past, folk aesthetics had generated a community-forging effect and an association with a particular vernacular, the changing understanding of bodily labor in the circus performances of the late 1960s allowed for new dramaturgical revue structures. These included, for example, Revue-Akademie, 1. Lektion (Revue Academy, 1st Lesson, 1968), a revue that pretended that it was teaching the genre's rules to emerging artists in the field; Warenhaus der guten Laune (Department Store of Joy, 1960 and 1969), which explored the happy sides of GDR consumer culture in a Berlin department store; and $R$ wie Revue ( $\mathrm{R}$ as in Revue, 1972), which demonstrated the idiosyncrasies of revue dances in tableaux that were inspired by the letters of the alphabet, (e.g., E for Erotic). The turn toward dance-centered revues starting in the mid-1960s required that the body be recognized as a bearer of meaning in its own right. Socialist virtuosity allowed dancers in East Germany to investigate the processes of aestheticized performance. In the light of Herrmann's socialist handstand and the development of a socialist virtuosity, the power of the moving body to create meaning beyond narrative in variety theatre prefigured a similar shift in thinking in GDR theatre in general that has been recognized by other theatre scholars. Petra Stuber and Jens Richard Giersdorf, for instance, locate this dramaturgical shift in the late 1960s and early 1970s, when GDR theatre became more "playful and abstract." ${ }^{81}$ Since Herrmann had started this discussion around the body almost a decade earlier, it might be assumed that the bodies of GDR socialist performance prefigured its changing narratives.

In the 1960s and 1970s, Kropp and Schröter's idea of a classical-technical vortex was extended into revue in order to create an exaggerated, highly stylized form of show dance. In the 1970s the Friedrichstadt-Palast produced a new twohour-long revue extravaganza every month and therefore required techniques that allowed easy reproduction and customization of various folk and show dances. Although Groschopp claims that, throughout the 1970s, "the former core principles [of humanism] could be found only in ambitious reading matter," performers had in fact already accommodated its principles in their practices and developed uniquely socialist aesthetics. In 1976, dance scholar Werner Gommlich critiqued the terpsichorean revues for failing to develop new dances in favor of maintaining standardized techniques and modifications of what already existed. He especially took issue with the glorification of classical technique: "the wide-spread fallacy that a kind of modification of traditional forms of stage dance - for instance, through classical technique - meets the requirements of the entertaining arts must be overcome." ${ }^{83}$ In critiquing socialist virtuosity's potential to generate socialist-realist performances, Gommlich thinks of these strategies as failing to satisfy the needs of an ever-advancing socialist society. He understands the classical-technical vortex itself as sedimented, failing to make relevant points about the moving bodies' capacities to render a socialist reality. The scripts of affect that Lauckner and Turra summarized in 1964 might have been relevant in their time, but they seemed to have lost their significance by the end of the 1970s. 


\section{Theatre Survey}

The socialist handstand had been a means to structure hope by turning to the body as a vehicle of socialist meaning. But as soon as these ideas became overburdened by the imperative to control and standardize cultural production through the classical-technical vortex, the concept seemed to lose its potential to create affect in socialist terms. Lauckner and Turra started to name the conversations that socialist virtuosity was meant to spark in the mid-1960s. But these conversations and the techniques they eventually entailed have never been updated for the socialist revue, causing these scripted affects to lose their appeal, as Gommlich suggests. Decades later an ideologically determined postreunification reading of GDR culture has obscured the potential of socialist virtuosity as an artistic concept for the creation of a distinct nonbourgeois aesthetic. In correcting this historiographical tendency, there emerges the possibility that socialist virtuosity-in which labor made visible provokes a new relation between the performing body and the spectator-might offer some renewed ability to produce meaning beyond the specific historical moment of GDR state socialism.

\section{ENDNOTES}

1. Gottfried Herrmann, "Noch keine einheitliche Linie in der heiteren Kunst," Artistik 12 (1959): 4-5, at 4. All translations are mine unless otherwise indicated.

2. Wolfgang Jansen, Glanzrevuen der zwanziger Jahre (Berlin: Edition Hentrich, 1987), $128-66$.

3. Marion Kant, "Was bleibt? The Politics of East German Dance," New German Dance Studies, ed. Susan Manning and Lucia Ruprecht (Urbana, Chicago, and Springfield: University of Illinois Press, 2012), 130-46, at 130.

4. Jens Richard Giersdorf, The Body of the People: East German Dance since 1945 (Madison: University of Wisconsin Press, 2013), 24.

5. Wolfgang Schumann, Friedrichstadtpalast: Europas größtes Revuetheater (Berlin: Henschel Verlag, 1995), 40-2, quote at 40.

6. Birgit Walter, "Seit zwanzig Jahren steht der Friedrichstadtpalast in der Friedrichstraße: Es gibt keinen sozialistischen Handstand," Berliner Zeitung, www.berliner-zeitung.de/seit-zwanzigjahren-steht-der-friedrichstadtpalast-in-der-friedrichstrasse-es-gibt-keinen-sozialistischen-handstand15705726, last modified 27 April 2004; accessed 25 October 2015.

7. Horst Groschopp, Der ganze Mensch: Die DDR und der Humanismus-Ein Beitrag zur deutschen Kulturgeschichte (Marburg: Tectum Verlag, 2013), 15.

8. Giersdorf, 8.

9. This article departs from the ideological assumption that the creation of the GDR took place because the working class of East Germany initiated it. It therefore assumes a position that reflects the dominant cultural narrative of the time and the general conviction of the working-class members. In fact, the creation of the country had long been planned by communist expatriates in Moscow. (On the influence of German communist expatriates in Moscow see Groschopp, 14.)

10. Joachim Streisand, Kultur in der DDR: Studien zu ihren historischen Grundlagen und ihren Entwicklungsetappen ([East] Berlin: VEB Deutscher Verlag der Wissenschaften, 1981), 183-7.

11. Richard Schechner, Between Theater \& Anthropology (Philadelphia: University of Pennsylvania Press, 1985), 33.

12. Marion Kant, "German Gymnastics, Modern German Dance, and Nazi Aesthetics," Dance Research Journal 48.2 (2016): 4-25, at 8.

13. Reinhard Klooss and Thomas Reuter, Körperbilder: Menschenornamente in Revuetheater und Revuefilm (Frankfurt am Main: Syndikat, 1980), 69. 


\section{"Of course there is no such thing as a socialist handstand, but ..."}

14. Alfred Kurella, Der ganze Mensch (Berlin: Tribüne, 1969), 10.

15. Heinz Lauckner, "Programmgestaltung und Regie im Zirkus," Artistik 8 (1960): 7-9, at 8.

16. Horst Blumenfeld, "Gleichgültigkeit wird zum Bumerang," Artistik 10 (1962): 1-2, at 1.

17. Mark Franko, The Work of Dance: Labor, Movement, and Identity in the 1930s (Middletown, CT: Wesleyan University Press, 2002), 9.

18. In the second constitution of 1968 , which primarily anchored the Socialist Unity Party (Sozialistische Einheitspartei Deutschlands, or SED) as tantamount to the socialist development of the country, "humanism" and "humanitarian virtues" were to be disseminated through culture (Groschopp, 22).

19. Ibid., 23.

20. Ibid., 26.

21. The Theater des Volkes, the Friedrichstadt-Palast's name during Nazi rule, closed its doors during the mobilization of civilian-associated resources in Germany's Total War on 1 September 1944; the last performance was Walter Kollo's Wie einst im Mai (The distant May). The Palast's stage house burned down following airstrikes in March 1945. It reopened under the creative leadership of Marion Spadoni, daughter of famed power juggler and later talent agent Paul Spadoni, on 17 August 1945. The theatre was closed for just under a year. When it reopened, the ensemble initially performed in front of the safety curtain, while the main stage area was being cleared of rubble. Officially, the high costs provided a reason for the city's magistrate to take over the Palast and place it under government control in 1947 (Schumann, Friedrichstadtpalast). 1975), 19.

22. Udo Bartsch et al., Unterhaltungskunst A-Z, ed. Gisela Winkler (Berlin: Henschelverlag,

23. Martin Sporck was in fact a pseudonym used by Gustav Just, who led the SED's art division at the time. Ralf Stabel, "Die große Geste-Der sozialistische Realismus im Ballett," Bewegung im Blick, ed. Claudia Jeschke and Hans-Peter Bayerdörfer (Berlin: Vorwerk 8, 2000), 213-24, at 217.

24. Martin Sporck, "Realismus im Tanz," Weltbühne 52.7, 24 December 1952, reprinted in Zur Diskussion: Realismus im Tanz, ed. Staatliche Kommission für Kunstangelegenheiten (Dresden: VEB Verlag der Kunst, 1953), 7-14, at 9.

25. Ibid., 14.

26. Giersdorf, 60.

27. Friedrichstadt-Palast, “April 1951: Polowetzer Tänze," program booklet ([East] Berlin: Friedrichstadt-Palast, 1951), n.p.

28. Ibid.

29. I am basing the idea of the book revue on the popular trend of the book musical in America. On the evolution of the American book musical see Lisa Gennaro, "Evolution of Dance in the Golden Age of the American 'Book Musical,"' in The Oxford Handbook of the American Musical, ed. Raymond Knapp, Mitchell Morris, and Stacy Wolf (Oxford: Oxford University Press, 2011), 45-61.

30. Friedrichstadt-Palast, "Oktober 1954: Einmal am Rhein," program booklet ([East] Berlin: Friedrichstadt-Palast, 1954), n.p.

31. Ibid.

32. Giersdorf, 29.

33. Ibid.

34. Rudy Koshar, From Monuments to Traces: Artifacts of German Memory, 1970-1990 (Berkeley: University of California Press, 2000), 21.

35. Stephen Brockmann, The Writers' State: Constructing East German Literature, 1945-1959 (Rochester, NY: Camden House, 2015), 112-13.

36. The magazine was ten to thirty-five pages long and came out monthly between December 1954 and February 1990. There were title changes: after December 1968, it continued as Unterhaltungskunst, from January 1989 it was called Journal für Unterhaltungskunst, and from March 1990 it was called Journal Art \& Action. Additionally, there are a number of specially edited inserts, between five and twenty-five pages each, authored by party functionaries, critics, scholars, dramaturgs, dancers, choreographers, musicians, cabaret artists, and circus performers on current issues in 


\section{Theatre Survey}

the revue arts, e.g., "Arts and Entertainment" (1964/4), "Revue Dance and Its Perspective" (1964/10), "Reception in the Entertainment Arts" (1969/1), "Creative Cooperation" (1975/3), "Aesthetics of Entertainment" (1984/1), "Rock Theatre" (1988/5).

37. Tilo Vogel, "Artistischer Nachwuchs richtig gefördert," Artistik 3 (1956): 1-2, at 1.

38. Inge Regener, "Die Perspektiven unserer Artistenausbildung," Artistik 5 (1961): 1-2, at 1.

39. Paul Bouissac, Semiotics at the Circus (Berlin: De Gruyter Mouton, 2010), 12.

40. Regener, 1.

41. Vogel, 2.

42. "Die erste Staatliche Artistenschule Deutschlands," Artistik 1 (1961): 4.

43. Harry-Heinz Neumann, "Artistenüberprüfung: Das Gebot der Stunde," Artistik 4 (1955): $1-2$, at 1 .

44. Joseph Roach, Cities of the Dead (New York: Columbia University Press, 1996), 26.

45. Ibid., 27.

46. Neumann, 1.

47. Friedrichstadt-Palast, "Ein Ball rollt um die Welt," program booklet ([East] Berlin: Friedrichstadt-Palast, 1959), n.p.

48. Bouissac, 22.

49. Werner Hoerisch, "Ein Ball rollt um die Welt: Gedanken eines Betrachters zu einem Programm des Friedrichstadt-Palastes, Berlin," Artistik 2 (1960): 9-11, at 9.

50. Ibid.

51. Program booklet, "Ein Ball rollt um die Welt."

52. For 4. Zentrale Delegiertenkonferenz der Gewerkschaft Kunst in Leipzig on 23 and 24 September 1959, see Artistik 11 (1959).

53. The validation process was based on an order from 5 June 1958, "Anordnung über die Ausstellung von Berufsausweisen für die Artistik und Kleinkunst" "OOrder for the issuance of vocational certificates for circus performers and the minor arts"), that required all practicing performers to achieve at least a minimum quality in their performances; Roland Weise, Handbuch der Artistik und Kleinkunst der Deutschen Demokratischen Republik und des sozialistischen Auslandes (Pößneck: Streitberger, 1962), 10. For figures see Otto Netzker in Artistik, 1959 (8): 1-3, at 1. From 1971, performers received an open-ended permit following audit; Bartsch et al., 310.

54. Herrmann, 4.

55. Heinrich Martens, quoted in Maja Lopatta, "Sie machen sich's nicht leicht," Artistik 6 (1962): $1-4$, at 1 .

56. Hans Obermann, "Die Schranken zwischen heiterer und ernster Muse müssen fallen," Artistik 11 (1959): 1-2, at 1.

57. Judith Hamera, Dancing Communities: Performance, Difference and Connection in the Global City (Basingstoke, Hampshire, UK: Palgrave Macmillan, 2007), 39.

58. Ibid., 5 .

59. Ibid.

60. Ibid., 4.

61. In the Palast revue Berliner Luft (Berlin Air, 1966), the categories of "bourgeois" and "cosmopolitan" were staged as undesirable by portraying Berlin throughout the decades, between 1906 and 1966. The closer the tableaux moved toward socialist Berlin, the merrier the scenes got. The finale was staged in front of an abstract rendering of Alexanderplatz, including the Berliner Fernsehturm (Berlin TV Tower), whose construction as the world's third largest structure (Kai Eckart, Den Wolken entgegen: Die höchsten Türme Deutschlands [Munich: Herbert Utz Verlag, 1998], 34) had in fact not even been finished at the time. Socialist Berlin, having been portrayed as a place of both cheerful folklore and technological advancement had, through cunning storytelling, disassociated itself from a perceived Western decadence.

62. Hamera, 6.

63. Ibid., 40.

64. Ibid., 39 . 


\section{"Of course there is no such thing as a socialist handstand, but ..."}

65. Manfred Jäger, Kultur und Politik in der DDR, 1945-1990 (Cologne: Nottbeck, 1994), 46.

66. Brockmann, 57-8.

67. Priya Srinivasan, Sweating Saris: Indian Dance as Transnational Labor (Philadelphia: Temple University Press, 2012), 12.

68. Heinz Lauckner and Mario Turra, Die Zirkuskunst in der Deutschen Demokratischen Republik, Informationen 7-8 (Berlin: Ministerium für Kultur, 1964), 6.

69. Hamera, 40.

70. Lauckner and Turra, 12; italics in original.

71. Lauckner, 8 .

72. Ibid.

73. Lauckner and Turra, 12.

74. Vicky Lebeau, “You're My Friend': River's Edge and Social Spectatorship," Camera Obscura 9.1-2 (1991): 250-73, at 256.

75. Waltraud Kropp and Heinz Schröter, Die Bedeutung der Tanzkunst für die artistische Arbeit, Informationen 2 (Berlin: Ministerium für Kultur, 1964), 4.

76. Nikolai I. Tarassow, Klassischer Tanz: Die Schule des Tänzers, trans. [from Russian] Werner Gommlich, ed. Martin Puttke-Voß (Berlin: Henschelverlag, 1974), 12.

77. Tarassow, 15.

78. Ibid.

79. Kropp and Schröter, 6.

80. Ibid., 4.

81. Petra Stuber, Spielräume und Grenzen: Studien zum DDR-Theater (Berlin: Christian Links, 2000), 9. See also Giersdorf, 50, 66-84.

82. Groschopp, 25.

83. Werner Gommlich, "Tanz: Terpsichore auf dem Vormarsch," Unterhaltungskunst 6 (1976): 4-7, at 7. 